\title{
Regulatory volume decrease in isolated nematocytes is affected by crude venom from the jellyfish Pelagia noctiluca
}

\author{
Rossana Morabito, ${ }^{1}$ Silvia Dossena, ${ }^{2}$ Giuseppa La Spada, ${ }^{3}$ Angela Marino ${ }^{3}$ \\ ${ }^{1}$ Department of Human and Social Sciences, University of Messina, Italy; ${ }^{2}$ Institute of Pharmacology \\ and Toxicology, Paracelsus Medizinische Privatuniversität, Salzburg, Austria; ${ }^{3}$ Department of \\ Biological and Environmental Sciences, University of Messina, Italy
}

\begin{abstract}
Crude venom from nematocysts of the Scyphozoan Pelagia noctiluca possesses hemolytic and cytotoxic power on cultured cells and elicits local and systemic inflammation reactions in vivo. The ability of regulating their volume after exposure to an anisosmotic solution is a fundamental feature common to cells from vertebrates and invertebrates, including Cnidarians. The aim of the present work is to assay whether crude venom from Pelagia noctiluca may affect the regulatory volume decrease (RVD) of nematocytes isolated from the Anthozoan Aiptasia mutabilis, here employed as a cell model. For this purpose, nematocytes were isolated by $605 \mathrm{mM} \mathrm{NaSCN}$ plus 0.01 $\mathrm{mM} \mathrm{Ca}{ }^{2+}$ application on acontia of Aiptasia mutabilis, while crude venom was obtained by sonication of a population of, respectively, 10,25 and 50 nematocysts/ $\mu \mathrm{L}(\mathrm{n} / \mu \mathrm{L})$. Isolated nematocytes were pre-treated for 30 min with crude venom, submitted to hypotonic stress and their osmotic response and RVD were measured optically. Our results show that, after exposure to crude venom, nematocytes were morphologically intact, as shown by the Trypan blue exclusion
\end{abstract}

Correspondence: Angela Marino, Department of Human and Social Sciences, University of Messina, viale Ferdinando Stagno D’Alcontres 31, 98166 Messina, Italy.

Tel.: +39.090 .6765214 - Fax: +39.090 .394030 .

E-mail:marinoa@unime.it

Key words: crude venom, RVD, nematocytes, Pelagia noctiluca, Aiptasia mutabilis.

Conflict of interests: the authors declare no potential conflict of interests.

Received for publication: 31 October 2014.

Revision received: 24 November 2014.

Accepted for publication: 24 November 2014.

(C) Copyright R. Morabito et al., 2014

Licensee PAGEPress, Italy

Journal of Biological Research 2014; 87:4813

doi:10.4081/jbr.2014.4813

This article is distributed under the terms of the Creative Commons Attribution Noncommercial License (by-nc 3.0) which permits any noncommercial use, distribution, and reproduction in any medium, provided the original author(s) and source are credited. test, but did not exhibit RVD. This effect was dose-dependent and reversed by the ionopho re gramicidin. The last observation suggests an inhibitory effect of venom on cell membrane ion transport mechanisms involved in RVD. Further studies are needed to verify this hypothesis and ascertain if a similar effect could be observed in human cells.

\section{Introduction}

Pelagia noctiluca (Cnidaria: Scyphozoa) is a jellyfish whose distribution in both temperate and cold seas, including north Atlantic and north Pacific, has been described, and is particularly abundant in the Mediterranean Sea. ${ }^{1,2}$ This jellyfish is provided with nematocytes, the stinging cells of Cnidaria used for prey capture, defense and locomotion. Nematocysts, produced by Golgi apparatus, possess a capsule wall containing an inverted tubule and a fluid matrix with different toxins. The application of an adequate chemico-mechanical stimulus ${ }^{3}$ elicits the rapid eversion of the tubule, adhering to or penetrating the prey integuments, thus injecting venom. This response, referred to as discharge, is one of the most rapid exocytotic phenomena known to date. ${ }^{4-7}$ The biological activity and toxicology of the compounds contained in the capsular fluid have been widely investigated. ${ }^{2,8,9}$ Specifically, the crude venom contained in Pelagia noctiluca nematocysts has been demonstrated to affect both cell and tissue functions, ${ }^{5,10,11}$ as demonstrated by different biological assays currently used to assess the toxicity of many other terrestrial and marine organisms. ${ }^{8,9,12}$ In particular, both hemolytic and cytotoxic properties of Pelagia noctiluca crude venom have been assessed, ${ }^{10,13-16}$ in line with other toxicological studies modeled on cultured cells ${ }^{8}$ and/or erythrocytes. ${ }^{16}$ In addition, Pelagia noctiluca crude venom can elicit both local ${ }^{17}$ and systemic ${ }^{11}$ inflammation reactions in rats, as a consequence of oxidative stress.

The ability of regulate the cellular volume is a fundamental homeostatic response found both in vertebrates ${ }^{18}$ and invertebrates. ${ }^{19,20}$ When exposed to a hypotonic extracellular medium, cells initially undergo to osmotic swelling [ the osmotic phase (OP)] and successively regulate their volume toward the resting values (RVD phase). The RVD phase is characterized by an obliged efflux of water, obtained by activating an efflux of ions and other osmotic substances.

On this basis, the aim of the present work is to verify the effect of Pelagia noctiluca crude venom, at non necrotic doses, on the homeostatic responses of nematocytes isolated from the Anthozoan Aiptasia mutabilis, chosen as a cell model. In particular, the response of nematocytes to hyposmotic shock (OP and RVD) $)^{19,21}$ has been monitored as a function of cell viability under venom treatment. 


\section{Materials and Methods}

\section{Crude venom preparation}

\section{Nematocysts isolation}

Specimens of the Scyphozoan Pelagia noctiluca were collected from the Strait of Messina (Sicily, Italy) and nematocysts were isolated as previously described. ${ }^{22}$ Shortly, oral arms were excised from each specimens and nematocysts were isolated by osmotic lysis of nematocytes in $4^{\circ} \mathrm{C}$ distilled water. The resulting suspension was filtered through plankton nets (100, 60 and $40 \mu \mathrm{m}$ mesh, respectively) and spun (for 5 min at $4000 \times g$ at $4{ }^{\circ} \mathrm{C}$ ) to discard debris. Isolated nematocysts were then counted in a Bürker chamber and processed for venom extraction or stored at $-20^{\circ} \mathrm{C}$ for later use.

\section{Crude venom extraction}

Samples containing 10, 25 or 50 nematocysts/ $\mu \mathrm{L}$ were re-suspended in artificial sea water (ASW) and sonicated 30 times for $20 \mathrm{sec}$ at 70 $\mathrm{MHz}$ on ice (Sonoplus; Bandelin, Berlin, Germany). Nematocyst debris was separated by centrifugation (for $10 \mathrm{~min}$ at $4000 \times g$ at $4^{\circ} \mathrm{C}$ ) and the supernatant was used for the biological assay. The venom concentration was expressed as the number of nematocysts/ $\mu \mathrm{L}(\mathrm{n} / \mu \mathrm{L})$ in the sample prior sonication.

\section{Regulatory volume decrease study}

\section{Specimens collection}

Specimens of Aiptasia mutabilis (Anthozoa) were collected in the Strait of Messina at 50-90 $\mathrm{cm}$ depth, maintained in a closed-circuit aquarium at $18-24^{\circ} \mathrm{C}$ and weekly fed with shrimps (Penaeus japonicus).

\section{Nematocytes isolation}

Nematocytes, classified as microbasic-mastigophore, ${ }^{23}$ were isolated from acontia of Aiptasia mutabilis, by treatment with an isosmotic solution of $605 \mathrm{mM}$ NaSCN plus $0.01 \mathrm{mM} \mathrm{Ca}{ }^{2+} .{ }^{24}$ Acontia, once excised from the trunk of the specimens, were washed with low- $\mathrm{Ca}^{2+} \mathrm{ASW}$ to remove mucus and then treated with an isosmotic solution of $605 \mathrm{mM} \mathrm{NaSCN}$ plus 0.01 $\mathrm{mM} \mathrm{Ca}{ }^{2+}$, for the nematocyte extrusion from the tissue. Substitution of the NaSCN solution first with a $\mathrm{Ca}^{2+}$-free ASW and then with complete ASW permitted cell isolation and restoration of physiological conditions. Isolated nematocytes were checked under a light microscope (Leica DMLS, 400× magnification; Leica Microsystems GmbH, Wetzlar, Germany) to ascertain their morphological integrity. They were kept at 10$12^{\circ} \mathrm{C}$ for $1 \mathrm{~h}$ and then used within $3 \mathrm{~h}$ from isolation for cell volume regulation tests. To establish the non-necrotic dose of crude venom, isolated nematocytes were treated with different venom concentrations and their morphological integrity was assessed by Trypan blue dye exclusion test.

\section{Regulatory volume decrease tests}

\section{Control tests}

One hour after nematocytes isolation, a make-shift perfusion chamber was assembled by placing double sided adhesive tape between a glass slide and coverslip containing isolated nematocytes, in order to allow for continuous perfusion during the entire test and substitution of experimental media. Cell volume experiments were performed on nematocytes chosen for their strong adhesion to the slide. To assess the cellular response to the anisosmotic shock, RVD control test consisted of three periods: $1^{\text {st }}$ period, isosmotic ASW $\left(\pi=1100 \mathrm{mosm} / \mathrm{kg}_{\mathrm{H} 20}\right)$ for $5 \mathrm{~min} ; 2^{\text {nd }}$ period, hyposmotic ASW ( $\pi=710 \mathrm{mosm} / \mathrm{kg}_{\mathrm{H} 20}$ ) for $20 \mathrm{~min}$; $3^{\text {rd }}$ period, isosmotic ASW for $5 \mathrm{~min}$.

\section{Crude venom effect on regulatory volume decrease response}

To test crude venom effect on RVD capability, isolated nematocytes were pre-treated with 10,25 or $50 \mathrm{n} / \mu \mathrm{L}$ crude venom for $30 \mathrm{~min}$ at room temperature in a damp room. After incubation with crude venom, nematocytes were quickly rinsed with ASW and submitted to RVD test with the protocol described above. Nematocytes treated for 30 min with $50 \mathrm{n} / \mu \mathrm{L}$ crude venom were also submitted to the following RVD test: period la $\left(1^{\text {st }}\right.$ a), isosmotic ASW for $5 \mathrm{~min}$; period $1 \mathrm{~b}\left(1^{\text {st }} \mathrm{b}\right)$, isosmotic ASW plus $1 \mathrm{mM}$ gramicidin for $6 \mathrm{~min}$; period $2\left(2^{\text {nd }}\right)$, hyposmotic ASW for $20 \mathrm{~min}$; period $3\left(3^{\text {rd }}\right)$, isosmotic ASW for 5 min. During each RVD test, about 30 images/nematocyte were taken with a phase contrast microscope (Leica DMLS, 400× magnification; Leica Microsystems $\mathrm{GmbH}$ ) connected to a video camera (CCD camera) and to a computer equipped with suitable software (Movie Maker; Microsoft Co., Redmond, WA, USA). To assess cell volume changes as a function of time, the cross sectional area (as an indication of cell volume) of each recorded image was measured and $\mathrm{A} / \mathrm{A}_{0}$ ratio calculated. A represents the cross sectional area of a nematocyte at a given time and $\mathrm{A}_{0}$ is the average of the cross sectional area of the same nematocyte in isosmotic ASW.

\section{Experimental solution and reagents}

Isosmotic ASW had the following composition (mM): $\mathrm{NaCl} 520, \mathrm{KCl}$ 9.7, $\mathrm{CaCl}_{2}$ 10, $\mathrm{MgCl}_{2} 24, \mathrm{MgSO}_{4} 28$, imidazole 5, $\mathrm{pH} \mathrm{7.65,} \pi=1100$ mosm $/ \mathrm{kg}_{\mathrm{H} 2 \mathrm{O}}$. Low $\mathrm{Ca}^{2+}$ solution had the following composition (mM): $\mathrm{NaCl} 520, \mathrm{KCl} 9.7, \mathrm{CaCl}_{2}$ 0.01, $\mathrm{MgCl}_{2} 24, \mathrm{MgSO}_{4} 28$, imidazole 5, pH 7.65, $\pi=1100 \mathrm{mosm} / \mathrm{kg}_{\mathrm{H} 2 \mathrm{O}}$. In the hyposmotic ASW NaCl concentration was reduced to obtain $\pi=710 \mathrm{mosm} / \mathrm{kg}_{\mathrm{H} 2 \mathrm{O}}$ ( $\sim 35 \%$ reduction of osmolality). All chemicals were purchased from Sigma (Sigma Aldrich, St. Louis, M0, USA).

\section{Statistics}

Data are shown as mean values \pm standard error of the mean. Each data set is derived from at least six individual nematocytes. The significance of the differences was tested using one- or two-way analysis of variance (ANOVA), followed by Dunnet's or Bonferroni's post-hoc test, as appropriated. $\mathrm{P}<0.05$ was considered as statistically significant.

\section{Results}

Nematocytes isolated from acontia of Aiptasia mutabilis are depicted in Figure 1A. The cytoplasm is located around the organoid (nematocyst) and volume modifications, due to crude venom or hyposmotic shock application, are limited to this thin rim. Nematocytes isolated in ASW and treated with crude venom deriving from a population of at least $90 \mathrm{n} / \mu \mathrm{L}$ exhibited morphological changes of the cytoplasm within

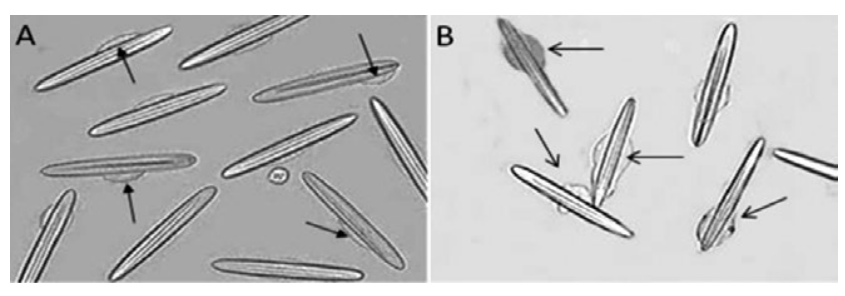

Figure 1. Morphological modifications and cell swelling in 90 $\mathrm{n} / \mathrm{mL}$ crude venom-treated cells (B) with respect to the control (A). Arrows indicate the cytoplasm, 200× magnification. 
10 min of treatment (Figure 1B). In particular, as depicted in Figure 1B, cell swelling was observed.

Viability of $90 \mathrm{n} / \mu \mathrm{L}$ crude venom-treated nematocytes within $10 \mathrm{~min}$ of treatment was confirmed by Trypan blue dye exclusion test. Nevertheless, after 30 min of treatment, cell necrosis was detected. On this basis, RVD assessment was performed on nematocytes treated with lower doses of crude venom, not leading to cell necrosis during 30 min of treatment.

\section{Regulatory volume decrease control tests}

Figure 2 shows the volume changes of isolated nematocytes in response to a reduction of extracellular osmolality from 1100 to 710 mosm $/ \mathrm{kg}_{\mathrm{H} 20}$. Following hyposmotic stress, cells rapidly swelled and after $10 \mathrm{~min} \mathrm{~A} / \mathrm{A}_{0}$ reached a peak value of $1.083 \pm 0.005$. This value was significantly higher than the values measured in isotonic solution during the $1^{\text {st }}$ period $(\mathrm{n}=6, \mathrm{P}<0.001)$. Within $20 \mathrm{~min}, \mathrm{~A} / \mathrm{A}_{0}$ returned to a value $(1.001 \pm 0.003)$ significantly lower than the peak value and not different from the values measured during the $1^{\text {st }}$ period, indicating that cells underwent complete RVD.

\section{Regulatory volume decrease in crude venom-treated nematocytes}

Figure 3 depicts nematocytes behavior following hyposmotic shock, after pre-treatment with different doses of crude venom (10, 25 or $50 \mathrm{n} / \mu \mathrm{L})$.

In the first case, nematocytes were pre-treated with a dose of venom corresponding to $10 \mathrm{n} / \mu \mathrm{L}$ (Figure 3A). Following application of the hyposmotic challenge ( $2^{\text {nd }}$ period), an increase in $\mathrm{A} / \mathrm{A}_{0}$ ratio was observed, corresponding to $\mathrm{OP}$. $\mathrm{A}_{\mathrm{A}} \mathrm{A}_{0}$ reached a peak value of $1.080 \pm 0.005$ within $10 \mathrm{~min}$, a value significantly higher $(\mathrm{P}<0.001)$ than that of the $1^{\text {st }}$ period (incubation in isotonic solution). Through the $2^{\text {nd }}$ period, $\mathrm{A} / \mathrm{A}_{0}$ ratio gradually fell to $1.005 \pm 0.003$ after $20 \mathrm{~min}$, a value significantly lower than the peak value $(\mathrm{P}<0.001)$ but not different respect to that measured during the $1^{\text {st }}$ period, denoting complete RVD. After returning to the isosmotic medium $\left(3^{\text {rd }}\right.$ period), the cell volume was comparable to that observed during the $1^{\text {st }}$ period $(0.999 \pm 0.022)$ without a post-RVD regulatory volume increase (RVI). $\mathrm{A} / \mathrm{A}_{0}$ values of treated

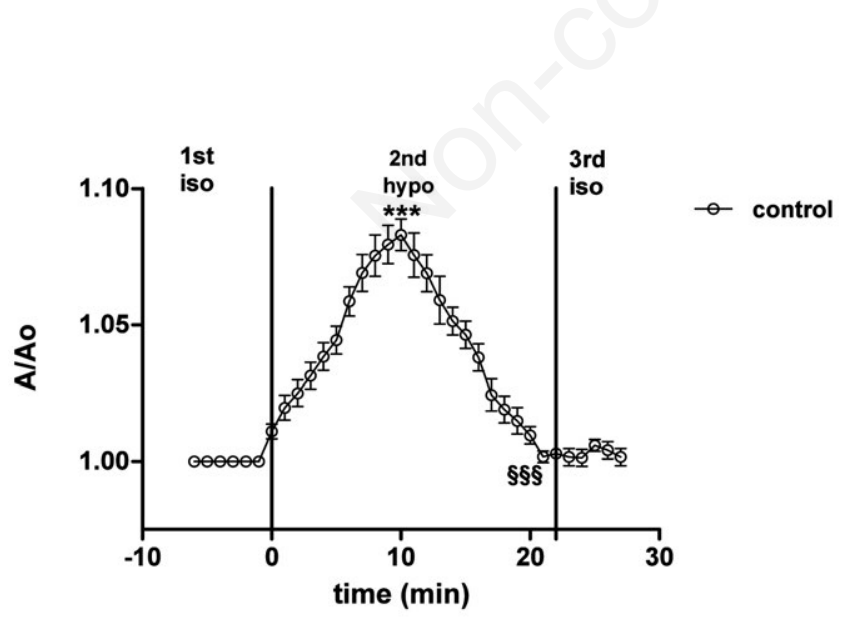

Figure 2. Effect of a hyposmotic challenge on isolated nematocytes. Cell volume, as $\mathrm{A} / \mathrm{A}_{0}$, is plotted against time. Following exposure to hyposmotic artificial sea water ( $2^{\text {nd }}$ period), nematocytes rapidly swell as expected for a perfect osmometer. After 10 min, regulatory volume decrease occurs despite the continued presence of a hyposmotic medium, and the initial volume is completely recovered after $20 \mathrm{~min}$. ${ }^{* * *} \mathrm{P}<0.001$ with respect to $\mathrm{A} / \mathrm{A}_{0}$ in isosmotic artificial sea water ( $1^{\text {st }}$ period); $\$ \$ \$ P<0.001$ with respect to the peak $A / A_{0}$ value.
A

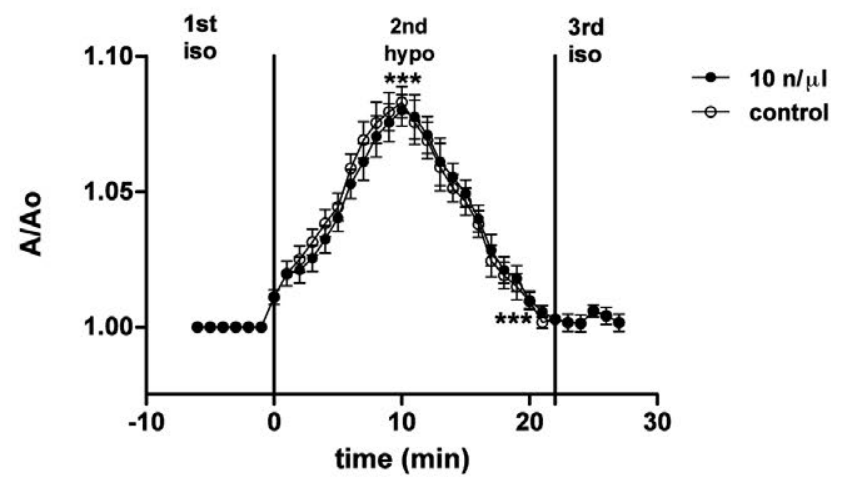

B

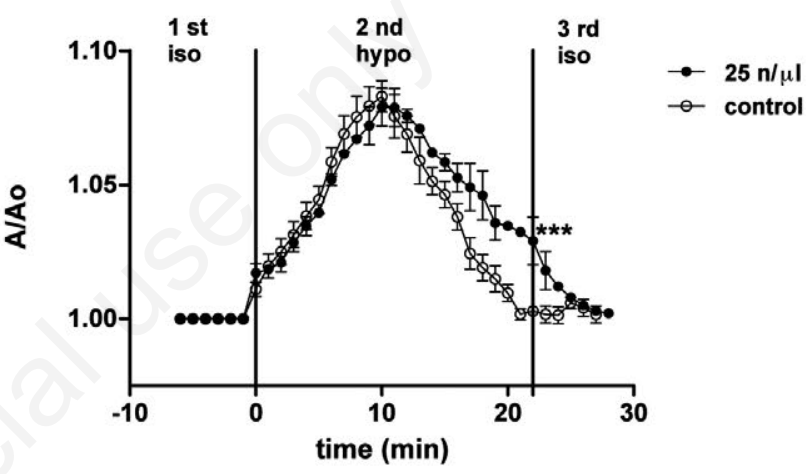

C

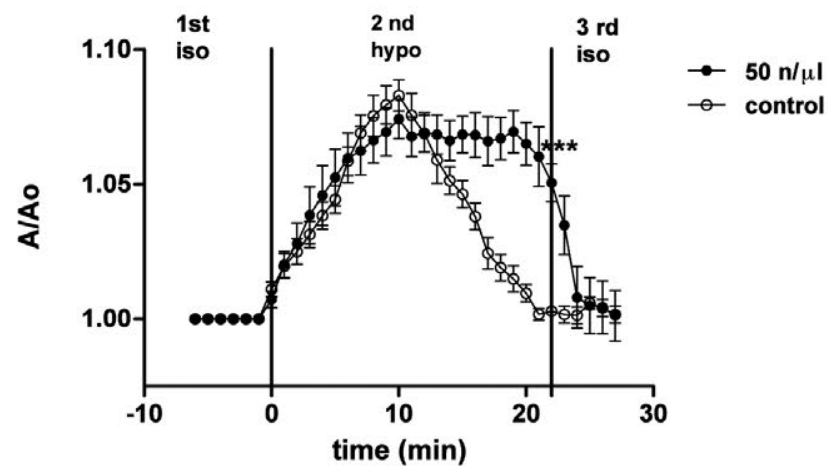

Figure 3. Effect of a hyposmotic challenge on isolated nematocytes pre-treated with different amounts of crude venom, from 10 (A), 25 (B) or $50(\mathrm{C}) \mathrm{n} / \mu \mathrm{L}$ respectively. Cell volume, as $\mathrm{A} / \mathrm{A}_{0}$, is plotted against time. In each experimental condition cell volume reaches a peak value significantly higher than the value measured before hyposmotic challenge. A) At the end of the $2^{\text {nd }}$ period, cell volume of treated cells decreases to a value significantly lower than the peak value $\left({ }^{* * *} \mathrm{P}<0.001\right)$ and not significantly different with respect to the corresponding value of untreated cells. B) At the end of the $2^{\text {nd }}$ period, cell volume of treated cells decreases to a value significantly lower than the peak value $\left({ }^{* * *} \mathrm{P}<0.001\right)$ and significantly higher than the corresponding value of untreated cells $(* * * P<0.001) . C)$ At the end of the $2^{\text {nd }}$ period, cell volume of treated cells is significantly higher than the value of untreated cells $\left({ }^{* * *} \mathrm{P}<0.001\right)$, and not significantly different with respect to the peak value of both treated and untreated cells. 
nematocytes were not different from those of control nematocytes, denoting that pre-treatment with 10 nematocysts/ $\mu \mathrm{L}$ crude venom did not affect OP or RVD.

In the second case ( $25 \mathrm{n} / \mu \mathrm{L}$ crude venom; Figure $3 \mathrm{~B}$ ), the application of hyposmotic shock induced cell swelling and $\mathrm{A}_{\mathrm{A}}$ reached the peak after 10 min $\left(1.079 \pm 0.005 ; 2^{\text {nd }}\right.$ period $)$. This value was significantly higher respect to the value observed before the hyposmotic challenge $(\mathrm{P}<0.001)$, but not different respect to the corresponding value of control nematocytes, denoting that the $\mathrm{OP}$ was not affected by exposure to crude venom. $\mathrm{A} / \mathrm{A}_{0}$ then decreased to control values, being unchanged the hyposmotic external medium, reaching $1.029 \pm 0.003$, at the end of the $2^{\text {nd }}$ period. This value was statistically different respect to the peak value and respect to the corresponding $\mathrm{A} / \mathrm{A}_{0}$ value observed in untreated cells $\left(1 \pm 0.001\right.$; end of $2^{\text {nd }}$ period), denoting that a partial RVD occurred. Substitution of hyposmotic solution with an isotonic one ( $3^{\text {rd }}$ period) induced a further gradual decrease in $\mathrm{A} / \mathrm{A}_{0}$

With regard to the third case ( $50 \mathrm{n} / \mu \mathrm{L}$ crude venom; Figure $3 \mathrm{C}$ ), during the $2^{\text {nd }}$ period cell volume significantly increased reaching a peak value of $1.074 \pm 0.005$ after 10 min of hyposmotic stress application. This value was significantly different respect to the value measured before the hyposmotic challenge $(\mathrm{P}<0.001)$ but not different respect to control, indicating that $\mathrm{OP}$ was not affected. At the end of the $2^{\text {nd }}$ period $\mathrm{A} / \mathrm{A}_{0}$ reached a value of $1.060 \pm 0.003$, not statistically different respect to the peak value, denoting that RVD was completely abrogated. Cell volume then decreased towards control values once the hyposmotic solution was substituted with an isotonic one ( $3^{\text {rd }}$ period).

In addition, RVD test was performed on $50 \mathrm{n} / \mu \mathrm{L}$ crude venom-treated nematocytes in the presence of gramicidin as a ionophore (Figure 4).

Cells exposed to an isosmotic solution plus $1 \mu \mathrm{M}$ gramicidin, did not exhibit significant changes in volume (period $1 \mathrm{~b}$ ) respect to control values. The application of a hyposmotic shock induced a notable increase in $\mathrm{A} / \mathrm{A}_{0}$, reaching the peak after $10 \mathrm{~min}(1.085 \pm 0.005$, a value significantly higher than that observed in isotonic conditions; $\mathrm{P}<0.001)$. At the end of the hyposmotic stress, $\mathrm{A} / \mathrm{A}_{0}$ fell to $1.022 \pm 0.003$, a value significantly different respect to both the peak value of treated cells and $\mathrm{A} / \mathrm{A}_{0}$ measured in untreated nematocytes at the end of the $2^{\text {nd }}$ period. These observations denote that gramicidin significantly ameliorated but did not completely restored RVD capability. Upon substitution of the hyposmotic solution with an isotonic one, cell volume further decreased to $1 \pm 0.001$ ( $3^{\text {rd }}$ period).

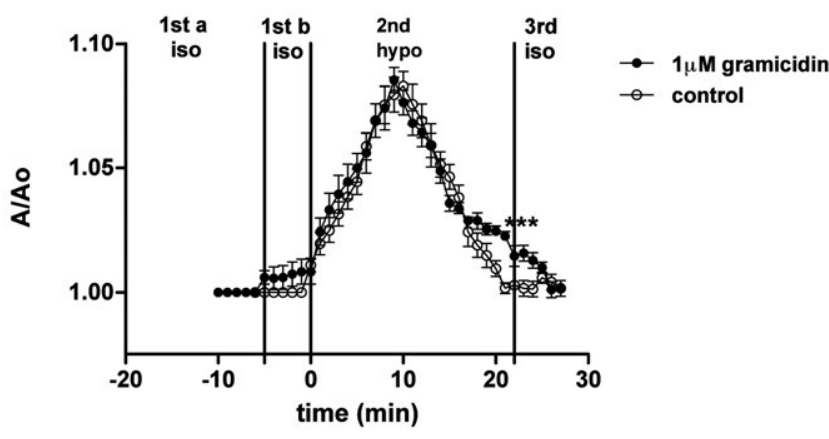

Figure 4. Effect of a hyposmotic challenge on isolated nematocytes pre-treated with $50 \mathrm{n} / \mu \mathrm{L}$ crude venom, and then exposed to $1 \mu \mathrm{M}$ gramicidin (period 1a). Cell volume, as $\mathbf{A} / \mathrm{A}_{0}$, is plotted against time. ${ }^{* * *} \mathrm{P}<0.001$ is compared to the peak value of gramicidin-treated cells and to the corresponding value of control cells.

\section{Discussion}

Venom extraction from isolated nematocysts is fine strategy for studying jellyfish toxins and is a needed step to learn more about their toxicological features, excluding other tissue-derived compounds. ${ }^{13,14}$ Investigations conducted on nematocysts isolated from Pelagia noctilu$c a$ have already shown that their venom elicits hemolytic activity on erythrocytes deriving from different sources, with a dose-dependent effect. ${ }^{13}$ Subsequently, it has been further demonstrated that the hemolytic power of this venom strictly depends on erythrocytes cell membrane damage. ${ }^{14}$ A pore formation onto cell membrane has been in fact supposed, and, subsequently confirmed using osmotic protectants, which impair the venom-induced hemolytic action. ${ }^{14}$

In an attempt to define more in detail the biological activity of Pelagia noctiluca crude venom on a cellular level, in the present work a functional parameter, rather than a morphological integrity assessment, has been adopted as a tool to verify the effect of crude venom. For this purpose, the capability of isolated nematocytes to regulate their volume in a hyposmotic medium following exposure to non necrotic doses of crude venom has been evaluated. In this regard, it has been already seen that isolated nematocytes of the Anthozoan Aiptasia mutabilis can regulate their volume after exposure to a hyposmotic medium, showing RVD within 20 min of hyposmotic shock. ${ }^{25}$ Permeability for $\mathrm{K}^{+}$ and $\mathrm{Cl}^{-}$is crucial during RVD response, similarly to what already reported for other cell types. ${ }^{18}$

The findings of the present investigation show that the exposure of isolated nematocytes to non necrotic doses of Pelagia noctiluca crude venom did not impair the osmotic cell swelling (OP) when the cells were submitted to $35 \%$ hyposmotic shock. In fact, cell volume reached a peak value within a time frame comparable to that observed for untreated nematocytes. Nevertheless, venom treatment dramatically inhibited the RVD response with a dose-dependent effect. Such observations lead to two considerations: from one hand, aquaporins function, known to be involved in $\mathrm{OP}^{26}$ presumably was not affected by the venom, whereas, on the other hand, the toxic effect seems to target ion conductances reported to play a major role in RVD phase. ${ }^{18}$ That cell membrane transport systems, namely at level of voltage-gated $\mathrm{Na}^{+}$and $\mathrm{K}^{+}$channels and acid-sensing ion channels, may be affected by marine toxins has been already ascertained. ${ }^{27}$ In this respect, palytoxin-group toxins (PITX) extracted from the tropical microalga Ostreopsis ovata, induces a massive intracellular $\mathrm{Na}^{+}$influx via modulation of the $\mathrm{Na}^{+} / \mathrm{K}^{+}$ATPase. ${ }^{28}$ The authors suggested that such $\mathrm{Na}^{+}$overload is the crucial step in oxidative stress-induced cell death in human HaCaT keratinocytes. More recently, Pelagia noctiluca crude venom has been demonstrated to interfere with the trans-membrane protein band 3 in human erythrocytes, by inhibiting the rate constant for anion transport. ${ }^{29}$ In particular, the authors hypothesized that crude venom may affect membrane proteins and cytoskeleton, with consequent ionic imbalance, providing the first evidence for a non lytic action of the venom on red blood cells and for a modulation of ion transport.

Cytoskeleton has been previously demonstrated to be essential during RVD in nematocytes isolated from Aiptasia mutabilis. ${ }^{25}$ Therefore, cytoskeleton re-arrangement, which normally follows the OP phase and is needed to restore the initial cellular volume, could be compromised as well by crude venom treatment. In this regard, other investigations have been attempted to link changes in cytoskeleton components with volume changes, and, more interestingly, to verify if drug-induced alterations of cytoskeleton affect cell volume regulation processes. ${ }^{30}$

In addition, non-lytic doses of crude venom from Pelagia noctiluca directly induce mitochondrial trans-membrane potential collapse and generation of reactive oxygen species (ROS) in neuronal-like (SHSY5Y) cells. ${ }^{15}$ Mitochondrial membrane alterations are possibly due to 
a pore-forming mechanism, leading to oxidative damage evidenced by both ROS generation and $\mathrm{m}$ decrease. Therefore, an oxidative damage by Pelagia noctiluca venom cannot be completely excluded, and is further supported by Marino and co-authors in a model of rat paw edema. ${ }^{17}$

The results of the present investigation lead to speculate that Pelagia noctiluca crude venom may affect membrane transport systems involved in RVD, rather than the cytoskeleton or the oxidative status of the cell. This hypothesis is supported by the finding that the ionophore gramicidin, associated to crude venom treatment, could at least partially restore RVD capability of isolated nematocytes, obscuring the inhibitory effect of the venom. Gramicidin has been already employed to restore RVD mechanisms when blocked in anthozoan nematocytes. ${ }^{31}$ Therefore, it is reasonable to hypothesize that the RVD inhibition observed here is the consequence of a blockage of ion conductances.

\section{Conclusions}

Pelagia noctiluca crude venom, at non-lytic concentrations, impairs RVD normally observed following hyposmotic shock in Aiptasia mutabilis nematocytes, without affecting the OP. Since RVD requires the activation of both $\mathrm{K}^{+}$and $\mathrm{Cl}^{-}$conductive pathways along with $\mathrm{KCl}$ cotransporter (KCC) under $\mathrm{Ca}^{2+}$ control and an intact cytoskeleton, ${ }^{20,21,25,32}$ it is reasonable to suggest that venom treatment may have altered cell function at level of channels, transporters, cytoskeleton and/or signaling. This study suggests that the inhibition of RVD by crude venom could be the consequence of an inhibition of ion fluxes, that were effectively restored by the ionophore gramicidin. The comprehension of the molecular mechanism of action of Pelagia noctiluca venom is extremely useful to predict its impact on human health, and, on the other hand, may open the way to possible applications of its active components.

\section{References}

1. Daly Yahia MN, Batistic M, Lucic D, et al. Are outbreaks of Pelagia noctiluca (Forskal, 1771) more frequent in the Mediterranean basin? In: Gislason A, Gorsky G, eds. Proceedings of the Joint ICES/CIESM Workshop to Compare Zooplankton Ecology and Methodologies between the Mediterranean and the North Atlantic (WKZEM), February 2010. International Council for the Exploration of the Sea Publ., Copenhagen, Denmark, pp 8-14. Available from: http://www.vliz.be/en/imis?refid=144077

2. Mariottini GL, Pane L. Mediterranean jellyfish venoms: a review on Scyphomedusae. Mar Drugs 2010;8:1122-52.

3. Scappaticci AA, Kahn F, Kass-Simon G. Nematocyst discharge in Hydra vulgaris: differential responses of desmonemes and stenoteles to mechanical and chemical stimulation. Comp Biochem Phys A 2010;1157:184-91.

4. Anderson PA, Bouchard C. The regulation of cnidocyte discharge. Toxicon 2009;54:1046-53.

5. Morabito R, Dossena S, La Spada G, Marino A. Heavy metals affect nematocysts discharge response and biological activity of crude venom in the jellyfish Pelagia noctiluca (Cnidaria, Scyphozoa). Cell Physiol Biochem 2014;34:244-54.

6. Morabito R, Marino A, La Spada G. Nematocytes activation in Pelagia noctiluca (Cnidaria, Scyphozoa) oral arms. J Comp Physiol A 2012;198:419-26.

7. Morabito R, Marino A, Dossena S, La Spada G. Nematocyst dis- charge in Pelagia noctiluca (Cnidaria, Scyphozoa) oral arms can be affected by lidocaine, ethanol, ammonia and acetic acid. Toxicon 2014;83:52-8.

8. Suput D. In vivo effects of cnidarian toxins and venoms. Toxicon 2009;54:1190-200.

9. Lazcano-Pérez F, Román-González SA, Sánchez-Puig N, ArreguinEspinosa R. Bioactive peptides from marine organisms: a short overview. Protein Peptide Lett 2012;19:700-7.

10. Mariottini GL, Sottofattori E, Mazzei M, et al. Cytotoxicity of the venom of Pelagia noctiluca Forskal (Cnidaria: Scyphozoa). Toxicon 2002;40:695-8.

11. Bruschetta G, Impellizzeri D, Morabito R, et al. Pelagia noctiluca (Scyphozoa) crude venom injection elicits oxidative stress and inflammatory response in rats. Mar Drugs 2014;12:2182-204.

12. Chen KC, Lin RS, Chang LS. Involvement of mitochondrial alteration and reactive oxygen species generation in Taiwan cobra cardiotoxin-induced apoptotic death of human neuroblastoma SK-NSH cells. Toxicon 2008;52:361-8.

13. Marino A, Crupi R, Rizzo G, et al. The unusual toxicity and stability properties of crude venom from isolated nematocysts of Pelagia noctiluca. Cell Mol Biol 2007;53:994-1002.

14. Marino A, Morabito R, Pizzata T, La Spada G. Effect of various factors on Pelagia noctiluca (Cnidaria, Scyphozoa) crude venominduced haemolysis. Comp Biochem Phys A 2008;151:144-9.

15. Morabito R, Condello $\mathrm{S}$, Currò $\mathrm{M}$, et al. Oxidative stress induced by crude venom from the jellyfish Pelagia noctiluca in neuronal-like differentiated SH-SY5Y cells. Toxicol in Vitro 2012;26:694-9.

16. Li R, Yu H, Xing R, et al. Isolation and in vitro partial characterization of hemolytic proteins from the nematocyst venom of the jellyfish Stomolophus meleagris. Toxicol In Vitro 2013;27:1620-5.

17. Marino A, Di Paola R, Crisafulli C, et al. Protective effect of melatonin against the inflammatory response elicited by crude venom from isolated nematocysts of Pelagia noctiluca (Cnidaria, Scyphozoa). J Pineal Res 2009;47:56-69.

18. Hoffman EK, Lambert IH, Pedersen SF. Physiology of cell volume regulation in vertebrates. Physiol Rev 2009;89:193-277.

19. Morabito R, Marino A, Lauf PK, et al. Sea water acidification affects osmotic swelling, regulatory volume decrease and discharge in nematocytes of the jellyfish Pelagia noctiluca. Cell Physiol Biochem 2013;32:77-85.

20. Morabito R, Marino A, La Spada G. Heavy metals affect regulatory volume decrease (RVD) in nematocytes isolated from the jellyfish Pelagia noctiluca. Comp Biochem Phys A 2013;165:199-206.

21. Marino A, Morabito R, La Spada G, et al. Mechanisms of hyposmotic volume regulation in isolated nematocytes of the anthozoan Aiptasia diaphana. Cell Physiol Biochem 2010;26:209-18.

22. Salleo A, La Spada G, Falzea G, Denaro MG. Discharging effectiveness of lyotropic anions on nematocysts of Pelagia noctiluca. Mol Physiol 1983;6:19-26.

23. Mariscal RN. Nematocysts. In: Muscatine L, Lenhoff HM, eds. Coelenterate biology. New York, NY: Academic Press; 1974. pp 129-78.

24. La Spada G, Marino A, Sorrenti G. Pelagia noctiluca "blooming" in the Strait of Messina: preliminary studies on the applicability of two methods for isolating nematocytes. Mar Ecol 2002;23:220-7.

25. Marino A, La Spada G. Calcium and cytoskeleton signaling during cell volume regulation in isolated nematocytes of Aiptasia mutabilis (Cnidaria: Anthozoa). Comp Biochem Phys A 2007;147: 196-204.

26. Carbrey JM, Agre P. Discovery of the aquaporins and development of the field. Handb Exp Pharmacol 2009;190:3-28.

27. Al Sabi A, McArthur J, Ostroumov V, French RJ. Marine toxins that target voltage-gated sodium channels. Mar Drugs 2006;4:157-92. 
28. Pelin M, Ponti C, Sosa S, et al. Oxidative stress induced by palytoxin in human keratinocytes is mediated by a H+-dependent mitochondrial pathway. Toxicol Appl Pharm 2013;266:1-8.

29. Morabito R, Marino A, Romano P, et al. Sulphate and hloride-dependent potassium transport in human erythrocytes are affected by crude venom from nematocysts of the jellyfish Pelagia noctiluca. Cell Physiol Biochem 2013;32:86-95.

30. Opsahl JA, Ljostveit S, Solstad T, et al. Identification of dynamic changes in proteins associated with the cellular cytoskeleton after exposure to okadaic acid. Mar Drugs 2013;11:1763-82.

31. La Spada G, Biundo T, Nardella R, Meli S. Regulatory volume decrease in nematocytes isolated from acontia of Aiptasia diaphana. Cell Mol Biol 1999;45:249-58.

32. Marino A, Morabito R, La Spada G, et al. Evidence for aquaporinmediated water transport in nematocytes of the jellyfish Pelagia noctiluca. Cell Physiol Biochem 2011;28:1211-8. 